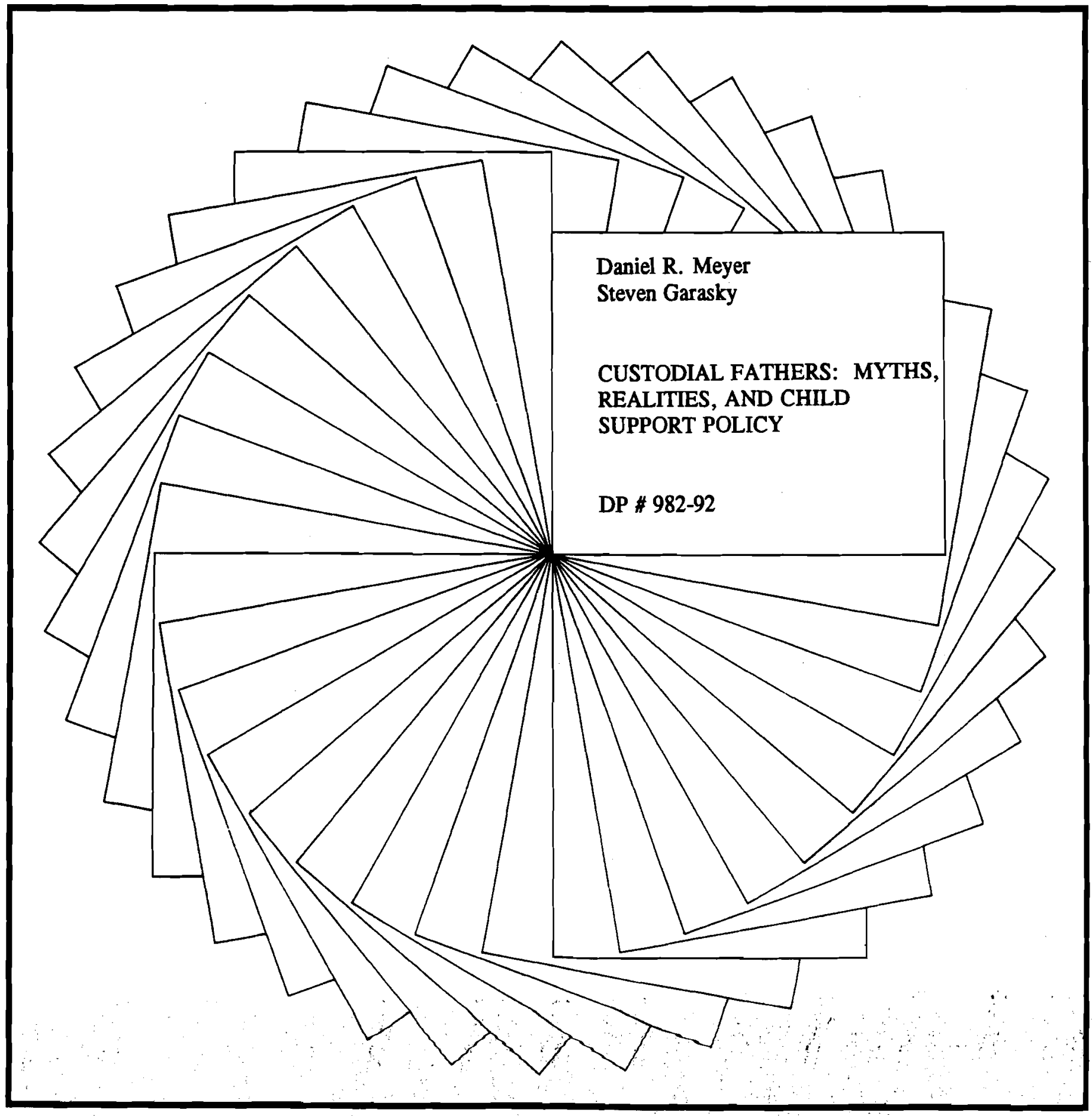


Institute for Research on Poverty

Discussion Paper no. 982-92

\title{
Custodial Fathers: Myths, Realities, and Child Support Policy
}

\author{
Daniel R. Meyer \\ School of Social Work \\ Institute for Research on Poverty \\ University of Wisconsin-Madison \\ Steven Garasky \\ Department of Human Development and Family Studies \\ Iowa State University
}

August 1992

An earlier version of this paper was completed when the authors were Economists at the Office of Human Services Policy, Assistant Secretary for Planning and Evaluation, U.S. Department of Health and Human Services, and was presented at the annual meeting of the Association for Public Policy and Management in Washington, D.C., October 1991. We would like to thank everyone in the Office of Human Services Policy for their helpful comments on an earlier draft of this paper and Donald Chontos and Charles Halla for their computer programming assistance. The views expressed in this paper are those of the authors and should not be construed as representing the official position or policy of the University of Wisconsin, Iowa State University, or the U.S. Department of Health and Human Services and any offices therein. 


\begin{abstract}
Men are increasingly receiving custody of their children, and single-father families with children are growing at a faster rate than even single-mother families. However, many observers still believe that custodial fathers are small in number. Indeed, there are a number of myths concerning custodial fathers, myths that are dispelled by empirical data. The authors examine data from the Current Population Survey, the Survey of Income and Program Participation, and Wisconsin court records, and determine that many assumptions about custodial fathers are simply not true. Many child support policies are founded on misconceptions about custodial fathers and custody arrangements themselves, especially the misconception that only mothers gain custody of their children. The authors argue that current child support policies should be reexamined to ensure that they follow the same principles when the custodial parent is the father as when the custodial parent is the mother.
\end{abstract}




\section{Custodial Fathers: \\ Myths, Realities, and Child Support Policy}

Much has been written about the explosion in the number of single mothers and its detrimental effects on children; on economic security, and, indeed, on society (for example, see Garfinkel \& McLanahan, 1986; Ross \& Sawhill, 1975). Very little, however, has been written about single fathers, yet this group is also rapidly increasing. In fact, as will be discussed in greater detail below, the number of father-only families has tripled since 1974, making them the fastest-growing family type in the United States today.

Much has also been written about child support policy. In almost all of these writings, however, policy analysts assume that mothers have custody of their children and fathers are absent. Indeed, the major data source on child support (the Current Population Survey-Child Support Supplement) did not include custodial fathers until 1992. We argue that child support policies should be reexamined to ensure that they are appropriate when fathers have custody of their children and mothers are absent.

We have found that whenever the lack of attention to single-father families (or custodial-father families, which would include fathers who have (re)married and have custody of the children from an earlier union) is mentioned, several reasons are given for why society does not need to be concerned. These reasons, however, rest on popular beliefs about these families rather than on empirical data. In Section II of this paper we present five "myths" about custodial fathers, including:

MYTH 1: THERE AREN'T VERY MANY FATHER-ONLY FAMILIES

MYTH 2: MOST CUSTODIAL FATHERS HAVE REMARRIED

MYTH 3: MANY OF THE SINGLE FATHERS ARE WIDOWERS AND VERY FEW HAVE NEVER BEEN MARRIED

MYTH 4: CUSTODIAL FATHERS HAVE HIGH INCOMES 


\section{MYTH 5: FATHERS PRIMARILY RECEIVE CUSTODY OF OLDER BOYS}

and examine three data sources (discussed in Section I) to discern whether these assertions are justified. In Section III, we provide more detailed descriptive information on the demographics of custodial fathers, their living conditions, their.welfare use, and their receipt of child support. We conclude with a discussion of the policy implications of our findings.

\section{DEFINITIONS, PRIOR STUDIES, AND DATA}

\section{Definitions}

Before examining the myths surrounding custodial fathers and child custody, we briefly discuss the two dimensions of custody: physical and legal. Most often when someone thinks of obtaining custody of a child or when statistics of custodial mothers and custodial fathers are cited, custody refers to physical custody. With which parent does the child spend the majority of his or her time? That parent is generally said to have "sole" physical custody of the child. If the child spends roughly an equal amount of time with each parent, then the parents are said to have "joint" physical custody of the child.

The parent with legal custody of the child generally makes any major decisions for him or her. As an example, the parent with legal custody generally determines which school the child will attend. It is much more common for parents to have joint legal custody of a child than it is for them to have joint physical custody. Overall, however, the most common custodial arrangement after divorce is for the mother to have both sole physical and legal custody (Seltzer, 1990). In this paper we focus on physical, rather than legal, custody. 


\section{Prior Studies}

While much of the literature relating to single-parent families has focused on families headed by mothers, there has been some research on father-only families. In 1976, Price-Bonham compiled a bibliography of 824 entries on fatherhood published after 1964.. Using books, articles, and dissertations, she divided the material into twenty-five categories, with one category specifically designated for "Fathers Alone and Single Fathers." Less than 2 percent of the entire bibliography (two books, thirteen articles, and one dissertation) fell into this category.

Since 1976, additional research has been completed on father-only families. Unfortunately, many of these studies suffer from limited data. Study sample sizes of forty or fewer divorced, separated, or widowed fathers are not uncommon (Bartz \& Witcher, 1978; Gasser \& Taylor, 1976; Gersick, 1979; Mendes, 1976; Orthner et al., 1976). Likewise, samples are often drawn from referrals (Mendes, 1976; Risman, 1986; Risman, 1987; Risman \& Park, 1988; Santrock \& Warshak, 1979); are self-selected through responses to questionnaires printed in support group publications (Greif, 1985; Greif, 1987; Risman, 1986; Risman \& Park, 1988); or are limited to small geographic regions such as metropolitan areas (Mendes, 1976; Santrock \& Warshak, 1979) or single states (Bartz \& Witcher, 1978; Chang \& Deinard, 1982; Christensen et al., 1990; Gasser \& Taylor, 1976;

Gersick, 1979; Orthner et al., 1976; Pearson et al., 1982; Pearson \& Thoennes, 1985; Rosenthal \& Heshet, 1981; Seltzer, 1990).

Many nationally representative data bases do not have enough custodial-father families to analyze them. For example, the National Survey of Children has only forty-five children living with their father and not their mother (Furstenberg et al., 1983). The only study reporting information from a large, nationally representative data base that has a significant number of cases is that by Zill (1988), who uses the Child Health Supplement of the National Health Interview Survey, conducted in 1981. Zill presents information on children in father-only families $(n=265)$, father-stepmother 
families $(n=216)$, mother-only families $(n=2759)$, mother-stepfather families $(n=1084)$, and motherfather families $(n=10,386)$.

The results from these prior studies are relatively consistent. The studies generally found custodial fathers to be white, middle aged, relatively well educated, occupying prestigious occupational roles, and receiving relatively high incomes. Often the comparison group for these studies are published national averages for fathers in two-parent households (Hanson, 1988). These comparisons are inappropriate and of limited value if the study data are not nationally representative.

Some researchers have attempted to select more-appropriate comparison groups. Risman (1986) and Risman and Park (1988) select a sample of custodial mothers in the same way they selected custodial fathers, from recruitment, press announcements, and referrals. Risman (1987) also selects intact families in the same way. Santrock and Warshak (1979) selected custodial mothers and intact families by individually matching them to the fathers in their sample. These comparison groups, while providing a point of reference for these studies, do not provide information that is generalizable to the status of custodial fathers in all of the United States.

Zill (1988) compared children in father-only families and in father-stepmother families to children in other family types using a nationally representative data base from 1981 . He found that children in father-only families were older, more likely to be male, and more likely to be black than children in all families; their fathers were less educated, and their families had somewhat lower incomes. Children in father-stepmother families were also older and more likely to be male. However, they were more likely to be white, to have parents with higher educations, and to have higher family incomes. Children in father-stepmother families showed the most behavioral and psychological problems of children in any family type, even after controlling for some of the differences between family types. Children in father-only families were significantly worse on these indicators than children in two-parent families, but somewhat better than children in mother-only 
families. Children in father-stepmother families and in father-only families were the most likely to repeat a grade and to have low class standings, and, more positively, to have the fewest days of school absence.

Many of these studies seek not to describe the characteristics of custodial fathers, but to understand the effects of this custodial arrangement on them and their children (Amato, 1987; Chang \& Deinard, 1982; Demo \& Acock, 1988; Glenn \& Kramer, 1987; Greif, 1985; Greif, 1987; Greif, 1990; Lewis, 1978; Mendes, 1976; Risman, 1986; Santrock \& Warshak, 1979; Stack, 1976). However, findings from these studies cannot be considered conclusive until they are corroborated by a larger sample of fathers with custody and an appropriate control group. Zill (1988) has provided the beginning work in this area; we update his numbers with more recent data, expand on them, and focus on fathers rather than children.

Data

For this review of custodial fathers, we have selected three different data sources: the Current Population Survey (CPS), the Survey of Income and Program Participation (SIPP), and the Wisconsin Court Record Database (WCRD). The CPS and SIPP allow for an analysis of custodial-father families at the national level. The WCRD, while not nationally representative, provides child support data with far superior detail than the other two surveys.

Current Population Survey. The CPS provides a variety of demographic and income data on a large, nationally representative sample. We have analyzed data from the 1990 CPS (which includes demographic information from March 1990 and income information from 1989) and the 1987 CPS (which includes demographic information from March 1987 and income information from 1986).

This data set has two difficulties when used for determining child custody. First, the CPS only asks for the relationship of everyone in the family to the family reference person, and not the relationships between all children and all adults in a family. As a result, we cannot differentiate 
between children who live with both parents and children who live with one parent and a stepparent. We thus use this data set to examine only father-only families and subfamilies, comparing them to mother-only families and subfamilies. This is not the entire group of custodial fathers, since some men with custody of their children have remarried. Second, some cohabiting couples may be incorrectly coded as single-parent families for the same reason we cannot identify remarried custodial parents. We cannot determine whether the partner of the reference person is also a parent to the child(ren) of the reference person. For our sample, we selected all families and subfamilies coded "other male head" (i.e., not "husband-wife families" or "other female head") that included an own, never-married child under age 18 . This provides 872 father-only families ( 814 without widowers) and 5309 mother-only families (4937 without widows). Although the number of cohabiting couples who have children living with them has grown rapidly (Spanier, 1983), only about 15 percent of the father-only families (125) contained men who were living with a female partner, and thus the children in these families may be living with both of their biological parents.

In April of 1988 (and in four previous Aprils), the CPS asked questions about child support and alimony in a special supplement (referred to as the Current Population Survey-Child Support Supplement, or CPS-CSS). Because only women were asked these questions, the CPS-CSS provides no information on custodial fathers, but does provide national information on custodial mothers (including remarried women) for reference. The 1988 CPS-CSS includes 4279 child support-eligible women.

Survey of Income and Program Participation. The SIPP is a nationally representative, multipanel longitudinal survey measuring economic and demographic characteristics of panel respondents over a $2 \frac{1}{2}$-year period. SIPP interviews are conducted once every four months and generally have two parts: a core questionnaire and one or more topical modules. The topical modules cover specific topics and vary with each interview. 
The data used for this study are from the Household Relationships topical module administered during the eighth interview cycle of the 1984 panel and the fourth cycle of the 1985 panel. SIPP is designed to have overlapping panels that allow for increased sample sizes when used for cross-sectional analysis.. Both panels were interviewed about their household relationships between January and April 1986.

Respondents were asked to identify the exact relationships among the persons living in the household at the time of the interview. Relationships between children and parents could be identified as natural, step, adoptive, foster, and unknown. For this study a father was determined to have custody of a child only if the child was his natural son or daughter and that child's natural mother was not part of the household. Adoptive and foster children were not considered. Custody is being implied by the presence in the household at the time of the interview of one of the child's natural parents and by the absence of the other natural parent.

The strength of the SIPP data over the CPS data is that biological relationships among all household members are known. Remarriage and cohabitation by fathers do not present problems when identifying custodial children since marital status is not an identification criterion. Weaknesses with these data stem from not knowing why the children are living with their father or mother and why the other parent is absent. The number of custodial fathers will be biased upward by including noncustodial fathers with visiting children and households with mothers who are only temporarily absent. The SIPP data identify 385 custodial fathers and 2114 custodial mothers.

Wisconsin Court Record Database. The WCRD is used to provide information on the child support awards and payments for custodial fathers and mothers. It is a sample of divorce, separation, and paternity cases from the family court records of twenty-one Wisconsin counties in which at least one child is potentially eligible for child support. (For a more complete description of the sampling design, see Garfinkel et al., 1988.) For this analysis we have used families that came to court 
between January 1984 and June 1987. In each year 30 to 150 cases were selected in each county, and if these cases came back to court, new information was collected. Because all child support payments are required to go through the courts in Wisconsin, this court record data base also includes monthly amounts of child support paid and owed. We have analyzed payment and award information from the period July 1, 1987, through December 31, 1987 (multiplying by two to get annualized figures). Selecting only cases that did not change physical custody during July to December 1987 and cases that did not have split or joint physical custody provides a sample of 392 custodial fathers and 4680 custodial mothers. Note that these custodial mothers and fathers are not representative of all custodial families because they are drawn only from families who have been through a court process; for example, some families who are informally separated and nonmarital unions in which paternity has not been established are not included.

\section{MYTHS AND REALITIES}

\section{Myth 1: There Aren't Very Many Father-Only Families}

Some authors use the terms "single-parent families" and "female-headed families" as synonyms (e.g., Ellwood, 1988). McLanahan and Booth (1989) comment that their review of singleparent families focuses only on mother-only families because, "Although interest in father-only families has been growing, the number of such families is still small--less than $10 \%$ of all one-parent families" (p. 575).

Figure 1 shows that the percentage of families with children headed by a single parent has grown significantly since 1960 , with this increase occurring for both mother-only and father-only families. Whereas there were less than 350,000 father-only families in 1959 , there were 1.4 million in 1989 , compared to 7.4 million mother-only and 25.5 million two-parent households. (Some of the 


\section{FIGURE 1}

\section{Family Types}

Families with Children Under 18

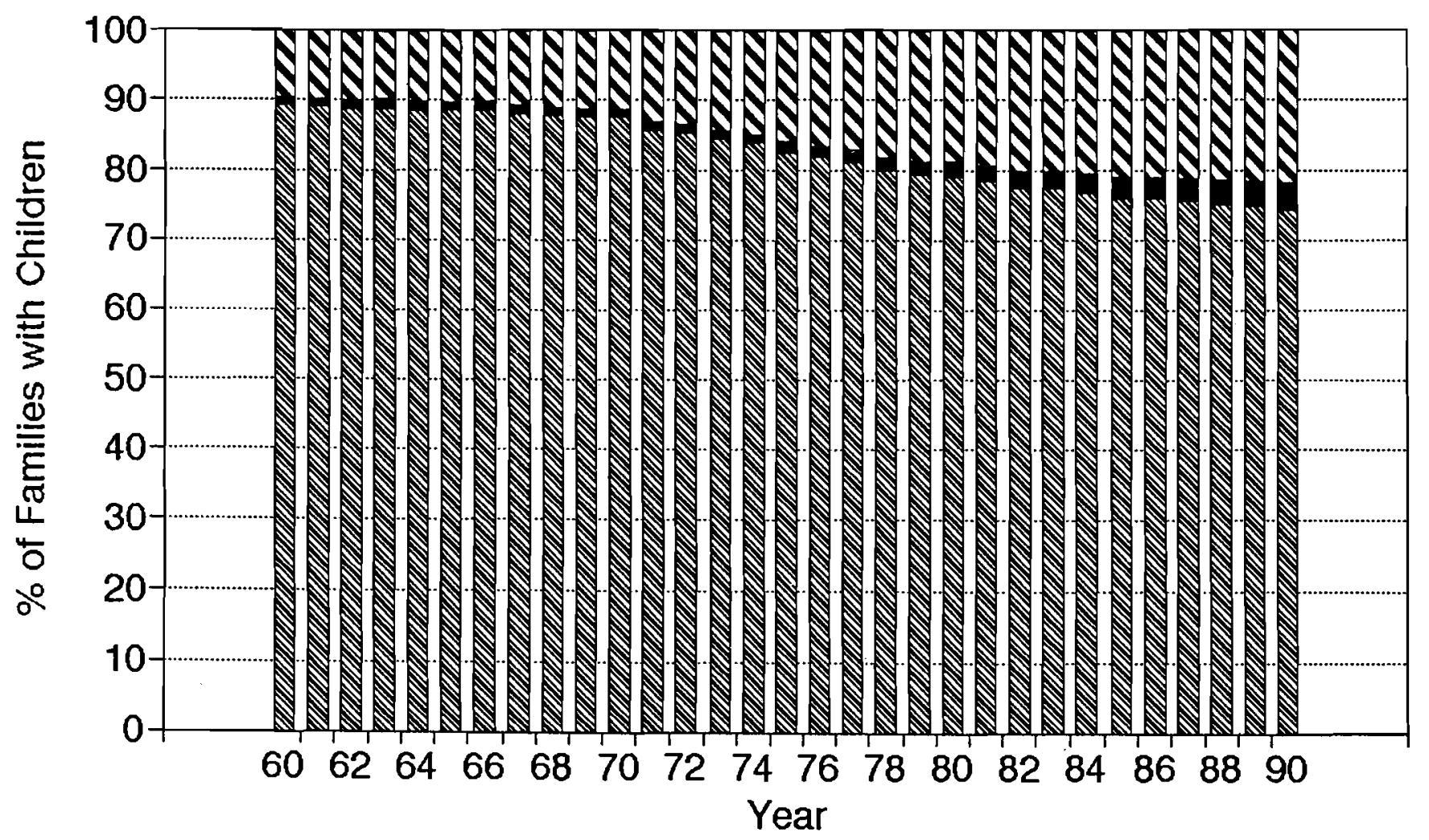

Married Couples Father-Only NV Mother-Only


children in these "two-parent families" are actually living with a father and a stepmother or a mother and a stepfather.)

But while the absolute number of father-only families is still a fairly small fraction of all families with children (about 4 percent), father-only families have been increasing dramatically in percentage terms. Figure 2 shows the growth in the number of families of each type since 1960 . Growth in two-parent families has been slight since 1960 . Mother-only families, in contrast, show a steady increase from about 1966 on. Father-only families have grown the fastest in this time period: between 1960 and 1990 the number of father-only families increased by almost 300 percent, compared to a growth rate of less than 200 percent for mother-only families. Perhaps more surprisingly, all of this growth occurred since 1974. This recent growth is consistent with findings from another national data set, the Panel Study of Income Dynamics (PSID). Hofferth (1985), using PSID data, found that the percentage of both white and black children living in father-only families was higher at every age for children born between 1975 and 1980 than for children born between 1960 and 1964.

Another way to look at this increase is in Figure 3, which compares the percentage of singleparent families that were headed by men from 1960 to 1990 . Here we can see that the percentage headed by fathers decreased from 1960 to 1974, but has been increasing steadily since. In summary, although father-only families have typically been ignored because of their small numbers, their rate of growth has been higher than that of mother-only families, and they now constitute more than 15 percent of all single-parent families.

\section{Myth 2: Most Custodial Fathers Have Remarried}

We can examine the current marital status of custodial fathers and mothers using data obtained in the winter of 1986 from SIPP. The SIPP estimated that in addition to the 858,000 singlefather families that were identified, there were 592,000 fathers who were currently married and had 
FIGURE 2

\section{Growth Among Family Types}

Families with Children Under 18

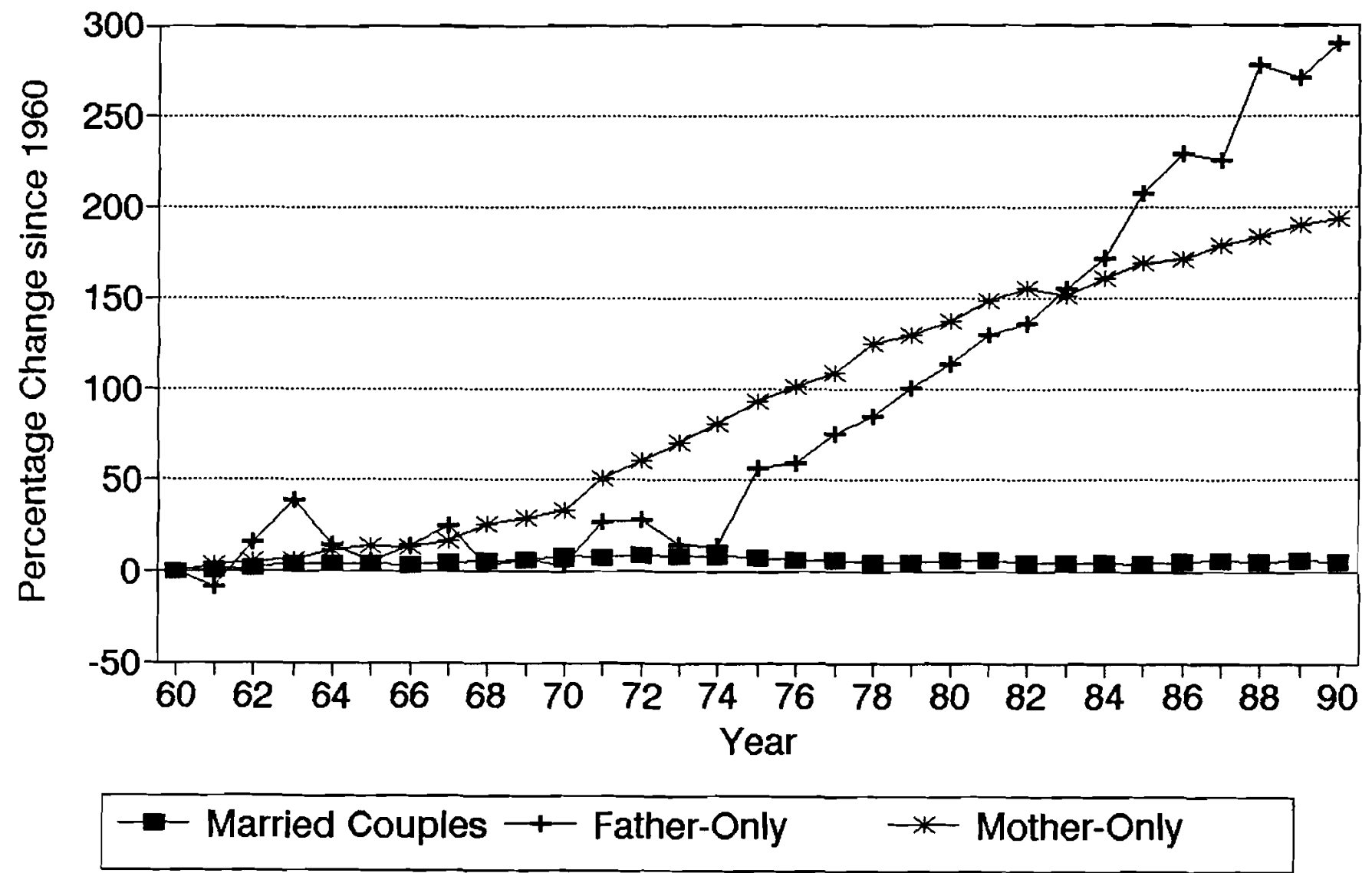


FIGURE 3

Percentage of Single-Parent Families Headed by Men

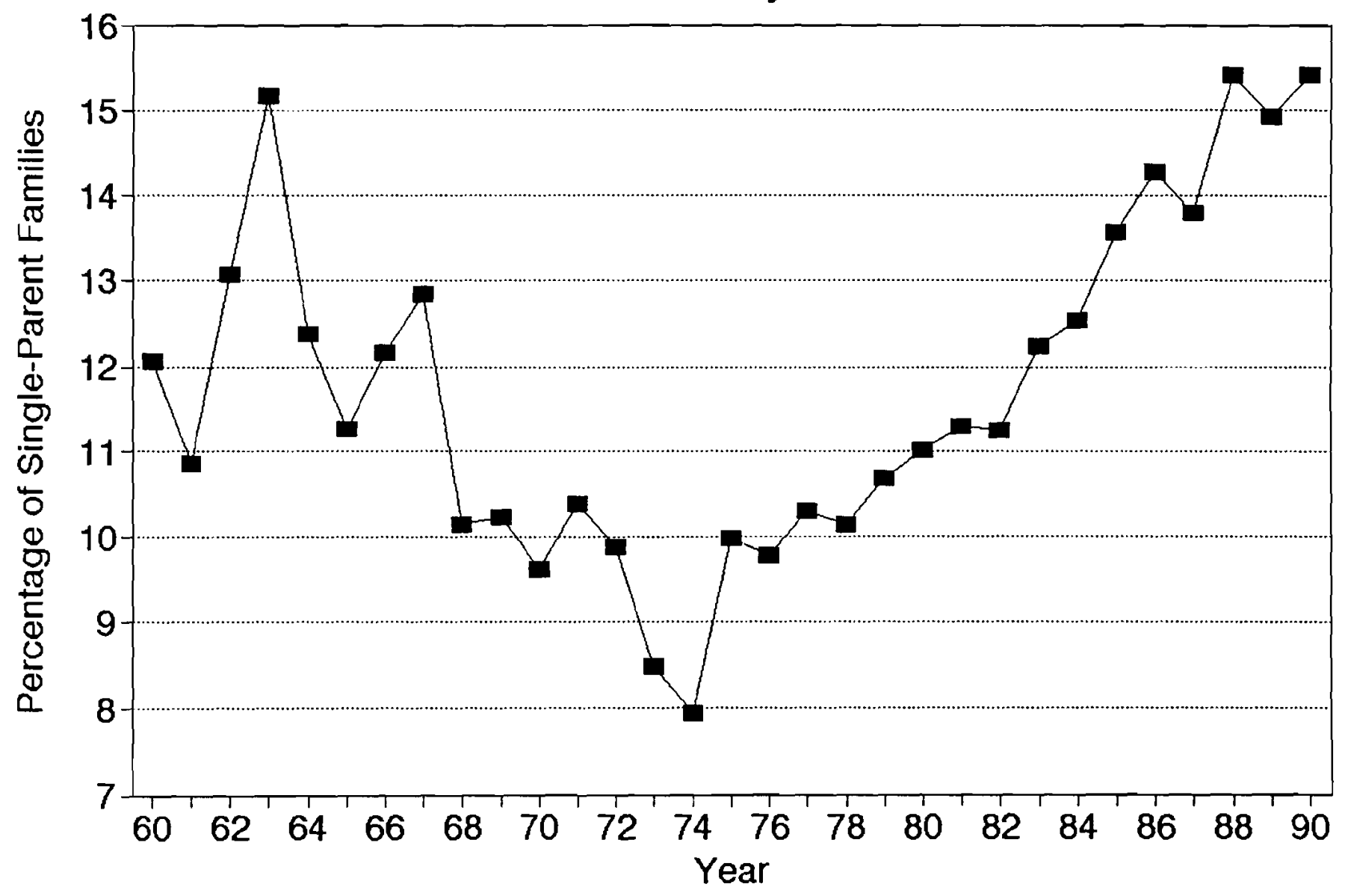


physical custody of their children. The majority (59 percent) of custodial fathers are currently unmarried, but the percentage of them who are remarried, 41 , is substantial and higher than the percentage of remarried mothers, 23 . As a result, looking only at fathers who are currently single provides an undercount of about $\mathbf{4 0}$ percent of the number of fathers with custody of their children. These comparisons are somewhat complicated because custody and marital status are not fixed states, but change over time. For example, some fathers may gain custody of their children after they remarry (perhaps because they appear to have a more stable home) rather than before.

\section{Myth 3: Many of the Single Fathers Are Widowers and Very Few Have Never Been Married}

An examination of the evidence in the CPS for these two beliefs about the marital status of single fathers reveals that while both may have been true in the past, neither is true today. Figure 4 shows that in 1970 very few children lived with fathers who had never married, and a fairly high percentage, 34.3, of the children in father-only families lived with widowers. However, as shown in Figure 5, between 1970 and 1990, the number of children living with never-married fathers increased dramatically, from 32,000 to 488,000 , while the number living with widowers decreased dramatically between 1970 and 1980 (from 262,000 to 172,000 ) and has since stabilized (150,000 in 1990). The number of children living with divorced fathers has also increased dramatically over this period (from 168,000 to $1,004,000$ ). Currently, of the children living in a single-parent family headed by their father, approximately 7.5 percent are in households headed by widowers and 24.5 percent are in households headed by never-married fathers (Figure 4).

The changes in the composition of father-only families by marital status actually are quite similar to the changes in the composition of mother-only families. While it is true that historically a higher percentage of father-only families than mother-only families were headed by widow(er)s, the difference had disappeared by 1990, as shown in Figure 6. 
FIGURE 4

Children in Single-Father Families, by Marital Status of Fathers

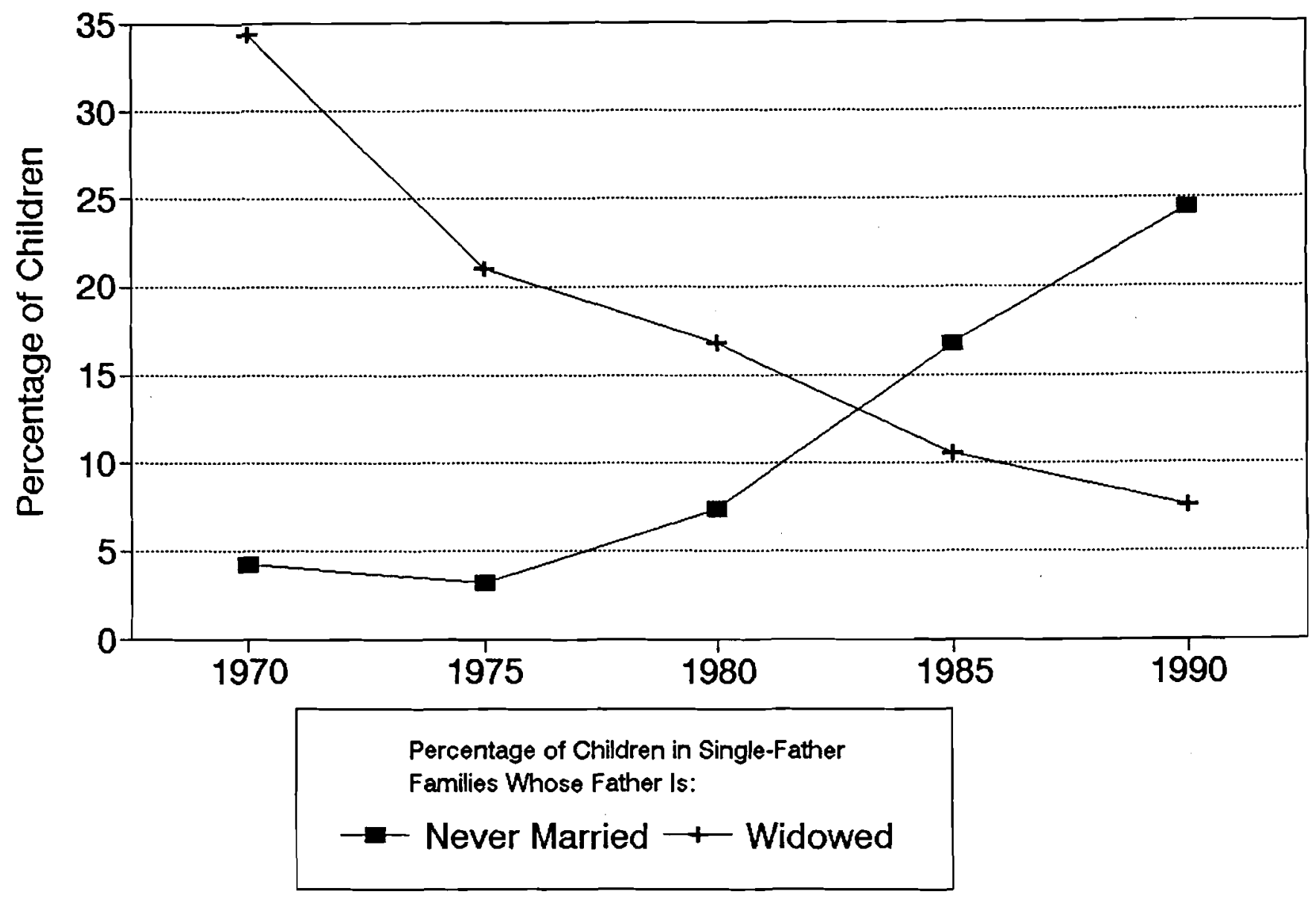


FIGURE 5

Children in Single-Father Families

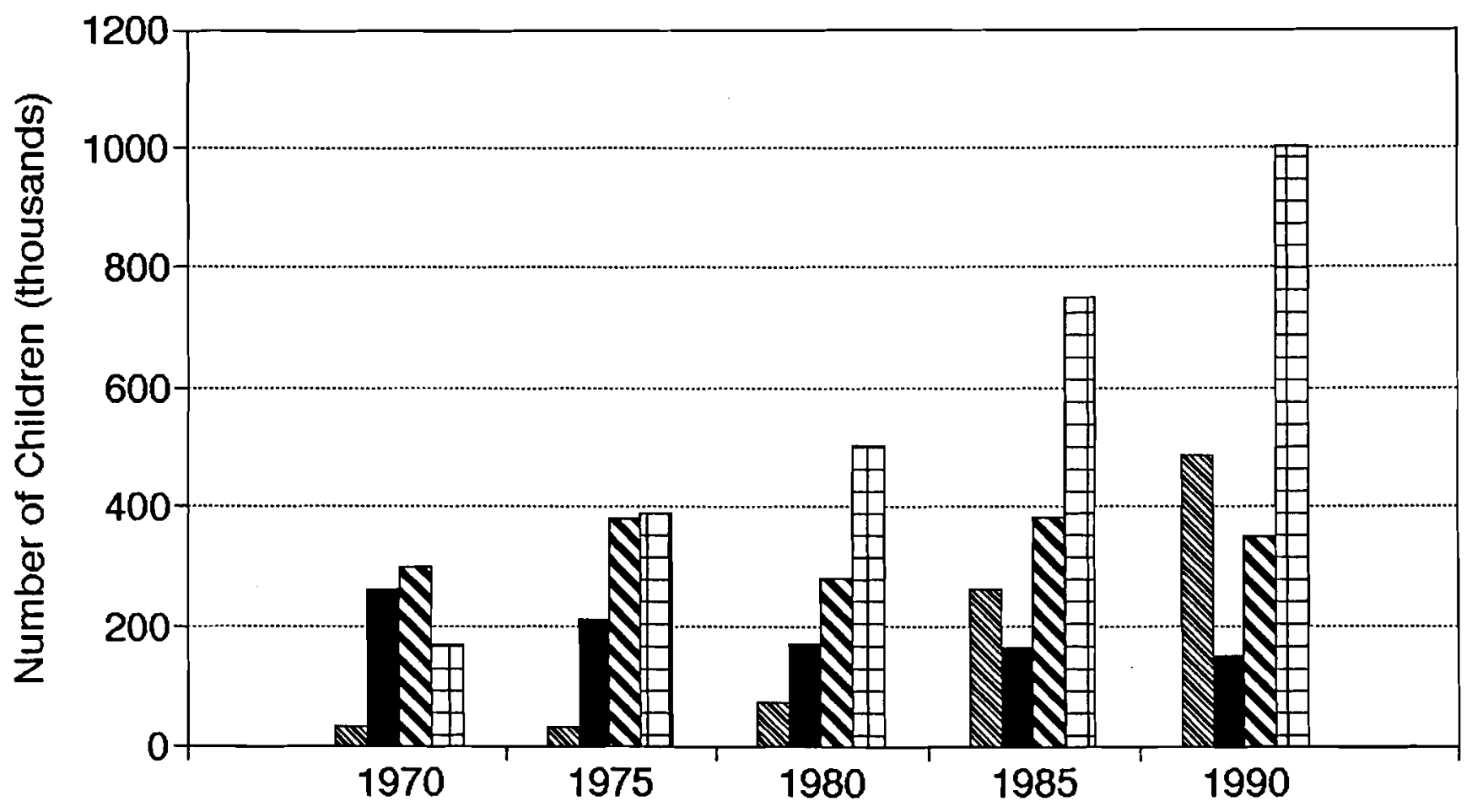


FIGURE 6

\section{Children in Single-Parent Families Marital Status of Parent}

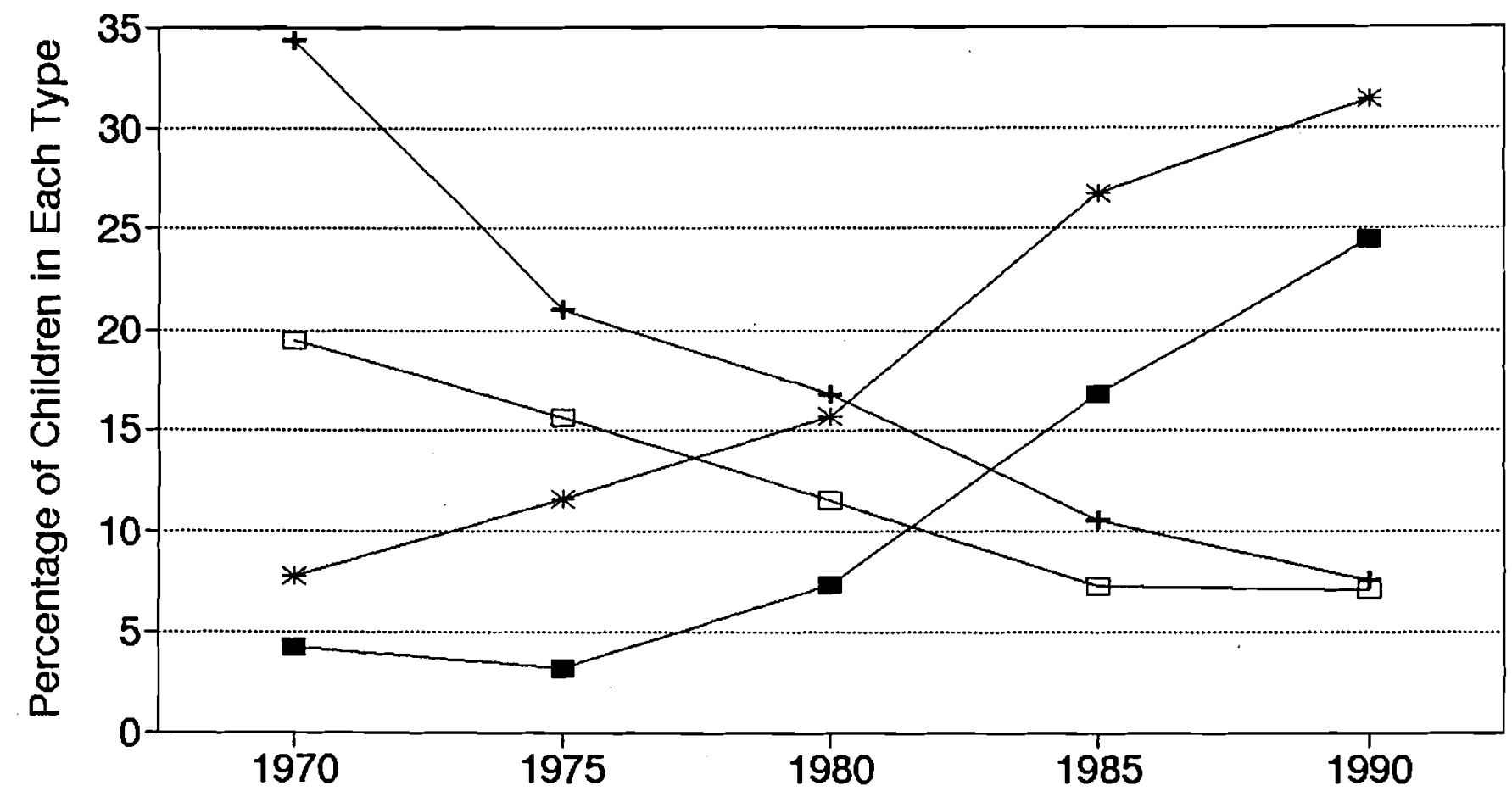

Percentage of Children in Single-Father Families Whose Father Is:

Percentage of Children in Single-Mother Families Whose Mother Is:

$\rightarrow$ - Never Married $\rightarrow$ Widowed $\quad *$ Never Married $\square-$ Widowed 
The number of father-only families headed by men who have never been married in the CPS is surprisingly much larger than anticipated. The SIPP estimate of the number of never-married father-only families is much smaller, about 100,000 in 1986 compared to 350,000 in the CPS in 1990. One reason for this discrepancy is that the number of never-married single fathers has grown rapidly during this time period: from the 1987 to the 1990 CPS the number increased from 209,000 to 345,000 , a 65 percent increase in three years. Although some of this increase may be due to the increase in children living with parents who cohabitate (Spanier, 1983), even in 1990 only one-third of the never-married fathers had a female partner living with them, and in some of these families she may not have been the child's mother.

In general, child support issues are not irrelevant for custodial fathers, since there is a living absent parent for over 90 percent of father-only families. In addition, in 1986 there were about 600,000 custodial fathers who had remarried. Child support is a relevant issue for these families as well. Because child support policies are a major focus of this work, all tables and figures in the remainder of this paper exclude widows and widowers.

\section{Myth 4: Custodial Fathers Have High Incomes}

Father-only families do have substantially higher incomes than mother-only families. The CPS estimates that in 1989 , mothers in mother-only families had a mean personal income of $\$ 12,959$, compared to a mean personal income for fathers in father-only families of $\$ 24,178$, or 187 percent of the mothers'. This difference is especially large for those parents who have never married, a group in which fathers have incomes 2.3 times as high as the incomes of mothers, and substantially smaller for those parents who are divorced, a group in which the incomes of fathers are 1.5 times as high as the incomes of mothers.

Even though the incomes of father-only families are substantially higher than those of motheronly families, a significant number of father-only families live in poverty. Data from the CPS that 
cover 1989 shown in Figure 7 reveal that 18.2 percent of father-only families with children under age 18 are poor, with almost half of these having family incomes less than half of the poverty line. Another 21.4 percent of these families have incomes between the poverty line and 199 percent of poverty. In comparison, married couples have much lower poverty rates (only 7.3 percent of married-couple families with children had incomes below poverty, and $\mathbf{1 7 . 2}$ percent had incomes between the poverty line and 199 percent of poverty), and mother-only families have much higher poverty rates ( 42.6 percent below poverty, and 26.2 percent between the poverty line and 199 percent of poverty).

This pattern of low incomes holds for all custodial fathers, not just for single-father families. Estimates of family incomes for all custodial fathers in 1985 from the SIPP include 11.8 percent with incomes less than the poverty line and another 26.6 percent with incomes between 100 percent and 199 percent of poverty. Thus, even though they are not as poor as custodial-mother families, a significant percentage of custodial-father families are very poor, and many more are near-poor.

\section{Myth 5: Fathers Primarily Receive Custody of Older Boys}

This myth really has two parts: first, that fathers primarily get custody of older children, and second, that fathers are more likely to get custody of boys.

The children living in father-only families are older than those living in mother-only families. However, some fathers do have custody of younger children. Table 1 shows that 17.5 percent of single-father families include children under age 3, and over 30 percent include a preschooler.

Similarly, the children in father-only families are more likely to be boys than girls, but many girls live in father-only families. Boys made up 56 percent of the children in father-only families in 1990 in the CPS and about 55.6 percent of the children in custodial-father families in 1986 in the SIPP. 


\section{FIGURE 7}

\section{Distribution of Families with Children by Poverty Status}

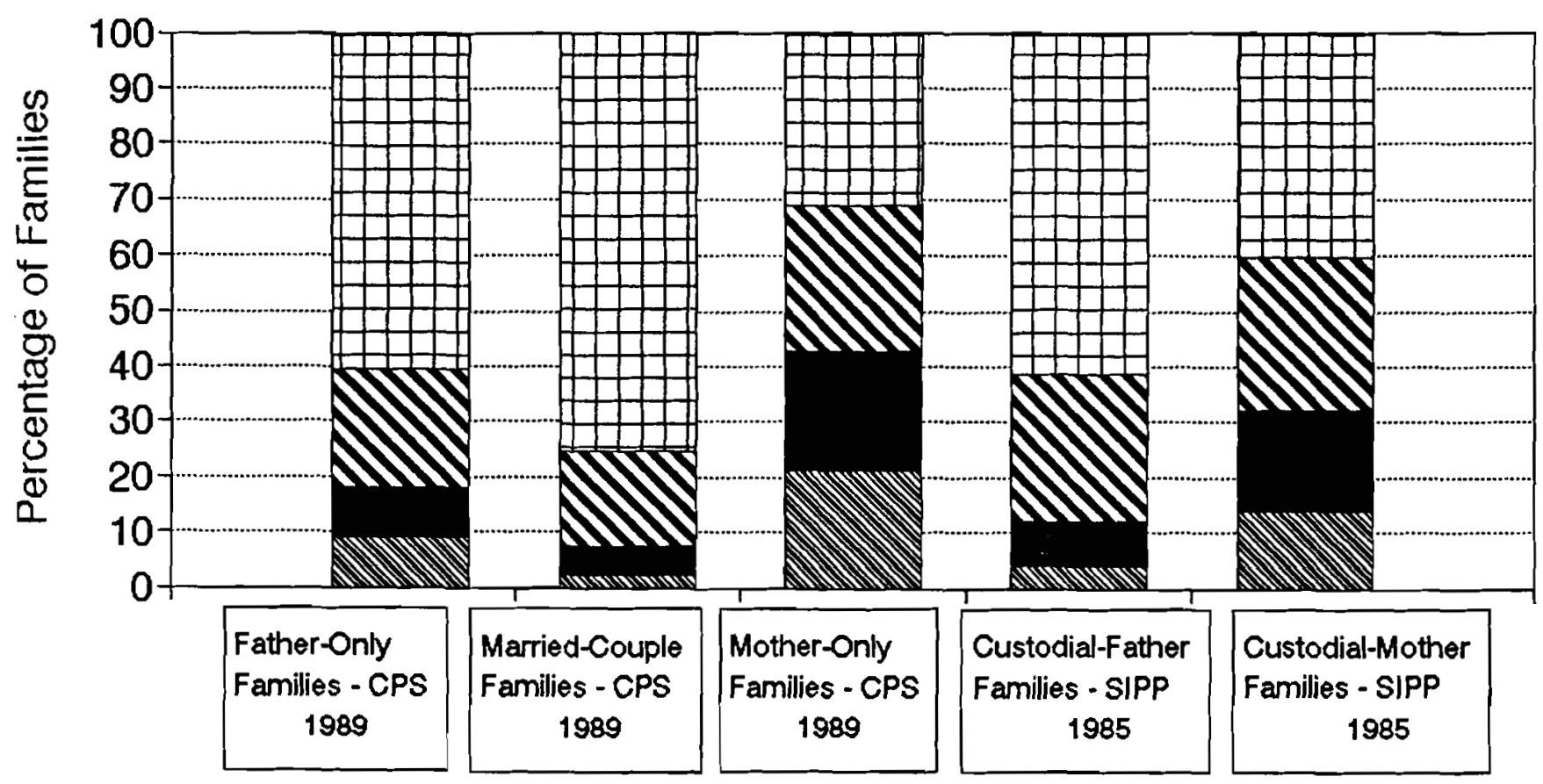


TABLE 1

Percentage of Single-Parent and Custodial-Parent Families with Youngest Child in a Particular Age Group: 1987 CPS and 1986 SIPP

\begin{tabular}{|c|c|c|c|c|}
\hline & \multicolumn{2}{|c|}{$1987 \mathrm{CPS}^{\mathrm{a}}$} & \multicolumn{2}{|c|}{1986 SIPP } \\
\hline & $\begin{array}{l}\text { Single-Father } \\
\text { Families }\end{array}$ & $\begin{array}{l}\text { Single-Mother } \\
\text { Families }\end{array}$ & $\begin{array}{l}\text { Custodial-Father } \\
\text { Families }\end{array}$ & $\begin{array}{l}\text { Custodial-Mother } \\
\text { Families }\end{array}$ \\
\hline \multicolumn{5}{|c|}{$\begin{array}{l}\text { Percentage of families with } \\
\text { youngest child between the } \\
\text { ages of: }\end{array}$} \\
\hline $\begin{array}{l}0-2 \\
3-5 \\
6-11 \\
12-17\end{array}$ & $\begin{array}{l}17.5 \\
14.9 \\
28.1 \\
39.6\end{array}$ & $\begin{array}{l}25.6^{*} \\
21.0^{*} \\
29.2 \\
24.2^{*}\end{array}$ & $\begin{array}{r}9.9 \\
17.2 \\
32.3 \\
40.6\end{array}$ & $\begin{array}{l}22.9^{*} \\
22.6 \\
30.4 \\
24.1^{*}\end{array}$ \\
\hline
\end{tabular}

Notes: Sample sizes: 681 single-father families and 4948 single-mother families in the CPS; 385 fathers and 1916 mothers in the SIPP. Widows and widowers were not included in either data source. Single-parent families contain only that parent and no other adult partner; custodial-parent families contain the biological parent of the child and another adult partner who is not biologically related to the child.

"A change in the coding of the ages of family members between the 1987 and the 1990 CPS makes the 1987 age information more accessible.

*The difference between the percentage of single mothers and single fathers (or custodial mothers and custodial fathers) is significantly different from zero at the .05 level. 


\section{DESCRIPTIVE INFORMATION ON CUSTODIAL FATHERS}

\section{Demographics}

Not surprisingly, generalizations about custodial fathers or single fathers depends on the comparison group, as seen in Table 2. Compared to married fathers with children, single fathers are more likely to be black, younger than 30 , and to have lower educations. On the other hand, custodial fathers are more likely to be white, older, and more highly educated than custodial mothers.

Drawing inferences from Table 2 must be done carefully, since we do not have information on matched pairs of fathers and mothers. For example, the fact that custodial fathers are more educated than custodial mothers does not necessarily mean that more-educated men are more likely to get custody than less-educated men-the numbers could simply be reflecting men's higher education level in general. Similarly, because custodial fathers are older than custodial mothers does not necessarily mean that older fathers are more likely to get custody.

What this snapshot does show is that custodial fathers could be expected to have higher incomes than custodial mothers since they are older, more likely to have college degrees, and less likely to be minorities.

\section{Living Conditions}

Table 3 details the living conditions of custodial fathers and mothers and married fathers. Again, the reference group is important. Single fathers have smaller families than married fathers, are more likely to live in central cities, more likely to live in the West, and more likely to live in subfamilies. Single fathers also have smaller families than single mothers. When remarried men and women are added, however, custodial fathers do not have significantly smaller families than custodial mothers. Single fathers are less likely to live in central cities, more likely to live in the West, and less likely to live in subfamilies than single mothers. 
TABLE 2

Demographic Information on Mothers and Fathers: 1990 CPS and 1986 SIPP

\begin{tabular}{|c|c|c|c|c|c|}
\hline & \multicolumn{3}{|c|}{1990 CPS } & \multicolumn{2}{|c|}{1986 SIPP } \\
\hline & $\begin{array}{l}\text { Single } \\
\text { Fathers }\end{array}$ & $\begin{array}{l}\text { Married } \\
\text { Fathers }\end{array}$ & $\begin{array}{l}\text { Single } \\
\text { Mothers }\end{array}$ & $\begin{array}{l}\text { Custodial } \\
\text { Fathers }\end{array}$ & $\begin{array}{l}\text { Custodial } \\
\text { Mothers }\end{array}$ \\
\hline \multicolumn{6}{|l|}{ Race } \\
\hline White & $80.3 \%$ & $87.8 \% *$ & $62.8 \%$ * & $84.9 \%$ & $70.1 \% *$ \\
\hline Black & 16.1 & $8.1^{*}$ & $34.8 *$ & 12.0 & $28.3^{*}$ \\
\hline Other & 3.5 & 4.1 & 2.4 & 3.1 & 1.6 \\
\hline Hispanic & 10.3 & 9.3 & 12.1 & 7.0 & 10.4 \\
\hline \multicolumn{6}{|l|}{ Age } \\
\hline Less than 21 & 2.2 & $0.5^{*}$ & $6.9 *$ & 0.7 & $6.9^{*}$ \\
\hline $21-30$ & 29.4 & $19.9^{*}$ & $36.4^{*}$ & 17.0 & $33.1 *$ \\
\hline $31-40$ & 36.7 & $45.2^{*}$ & 39.9 & 47.8 & $40.0^{*}$ \\
\hline $41-50$ & 23.9 & 27.5 & $14.6^{*}$ & 28.2 & $16.2^{*}$ \\
\hline 51 and over & 7.8 & 7.0 & $2.1^{*}$ & 6.3 & 3.8 \\
\hline \multicolumn{6}{|l|}{ Education } \\
\hline Less than 9 years & 8.8 & 6.3 & 7.2 & 6.3 & 6.0 \\
\hline $9-11$ years & 15.5 & $8.8^{*}$ & $19.7^{*}$ & 12.6 & $18.6^{*}$ \\
\hline 12 years & 41.7 & 37.4 & 45.1 & 43.2 & 45.4 \\
\hline $13-15$ years & 18.3 & 20.1 & 19.2 & 21.8 & 21.1 \\
\hline 16 years & 8.6 & $14.8 *$ & $5.5^{*}$ & 7.6 & 5.5 \\
\hline Over 16 years & 7.1 & $12.7^{*}$ & $3.2^{*}$ & 8.5 & $3.4^{*}$ \\
\hline
\end{tabular}

Note: Sample sizes: 814 single fathers, 16,402 married fathers, and 4937 single mothers in the CPS; 385 fathers and 2114 mothers (2046 for age) in the SIPP. Widows and widowers were not included in either data source. Single-parent families contain only that parent and no other adult partner; custodial-parent families contain the biological parent of the child and another adult partner who is not biologically related to the child.

*The difference between the percentage of single mothers and single fathers (or married fathers and single fathers, or custodial mothers and custodial fathers) is significantly different from zero at the .05 level. 
TABLE 3

Living Conditions of Mothers and Fathers: 1990 CPS and 1986 SIPP

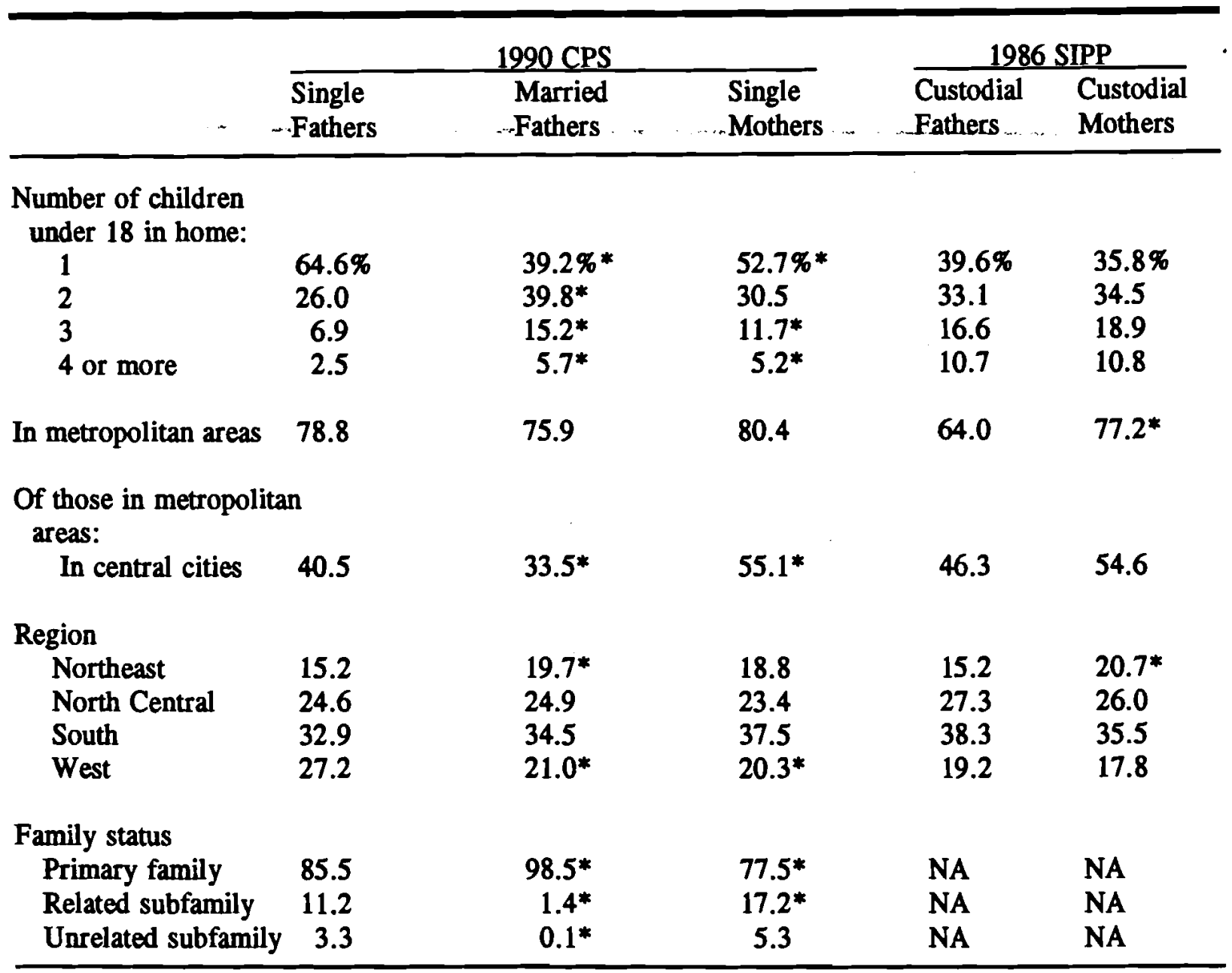

Notes: In six states, the SIPP masks the respondent's state of residence to maintain survey confidentiality. Mississippi and West Virginia are grouped together, but since both are in the South a regional designation is still possible. Idaho, New Mexico, South Dakota, and Wyoming are also grouped together; for this category we assigned 80 percent to be in the West and 20 percent in the North Central, based on the number of households in these four states. This simplification affects only 2.7 percent of the custodial fathers and 1.3 percent of the custodial mothers. Sample sizes: 814 single fathers (796 for metropolitan status and 446 for central city status), 16,402 married fathers (16,081 for metropolitan status and 8949 for central city status), and 4937 single mothers (4879 for metropolitan status and 3025 for central city status) in the CPS; 385 fathers (188 for metropolitan status and 128 for central city status) and 2114 mothers (2012 for number of children and 1638 for central city status) in the SIPP. Widows and widowers were not included in either data source.

*The difference between the percentage of single mothers and single fathers (or married fathers and single fathers, or custodial mothers and custodial fathers) is significantly different from zero at the .05 level. 


\section{Employment and Earnings}

Table 4 highlights employment and earnings information for custodial fathers, married fathers, and custodial mothers. The characteristics of single fathers are between those of married fathers and single mothers for each category: married fathers earn the most, followed by single fathers and then single mothers; married fathers work the most hours, followed by single fathers and then single mothers; and married fathers have the highest hourly wages, followed by single fathers and then single mothers. Although the economic situations of single fathers are better than those of

single mothers, economic security appears to be a concern for a significant number: about one-fourth of single fathers had personal earnings of less than $\$ 5000$, over one-third did not work full-time fullyear, and over 15 percent were earning less than $\$ 5.00$ /hour, a wage that, even if one were to work full-time full-year and had only one child, would provide an income that was only about 125 percent of the poverty line. Including currently married fathers and mothers in a comparison of custodial parents using the SIPP does not change these findings, although in these additional households two adults are available to contribute earnings to the overall household income.

\section{Welfare Recipiency}

Table 5 shows information on the use of welfare programs by custodial fathers and custodial mothers. Consistent with the higher incomes of custodial fathers, many fewer father-only families receive assistance from means-tested programs, with about 20 percent receiving assistance from at least one program, compared to more than 45 percent of mother-only families. The estimates from SIPP show a similar picture, with significantly fewer custodial-father families receiving assistance than custodial-mother families. 
TABLE 4

Employment and Earnings of Mothers and Fathers: 1989 CPS and 1985 SIPP

\begin{tabular}{|c|c|c|c|c|c|}
\hline & \multicolumn{3}{|c|}{1989 CPS } & \multicolumn{2}{|c|}{1985 SIPP } \\
\hline & $\begin{array}{l}\text { Single } \\
\text { Fathers }\end{array}$ & $\begin{array}{l}\text { Married } \\
\text { Fathers }\end{array}$ & $\begin{array}{l}\text { Single } \\
\text { Mothers }\end{array}$ & $\begin{array}{l}\text { Custodial } \\
\text { Fathers }\end{array}$ & $\begin{array}{l}\text { Custodial } \\
\text { Mothers }\end{array}$ \\
\hline \multicolumn{2}{|c|}{ Annual personal earnings } & - & & $\cdots$ & \\
\hline$\$ 0$ & $16.3 \%$ & $12.0 \% *$ & $31.1 \% *$ & $10.1 \%$ & $30.9 \% *$ \\
\hline$\$ 1-\$ 4999$ & 7.6 & $3.6^{*}$ & $15.2^{*}$ & 4.1 & $16.9^{*}$ \\
\hline$\$ 5000-\$ 9999$ & 9.5 & $4.8^{*}$ & $13.3^{*}$ & 5.4 & $15.9^{*}$ \\
\hline$\$ 10,000-\$ 19,999$ & 22.0 & $17.8^{*}$ & 23.4 & 30.6 & 26.1 \\
\hline$\$ 20,000-\$ 29,999$ & 19.5 & 21.0 & $10.8^{*}$ & 22.7 & $7.9^{*}$ \\
\hline$\$ 30,000-\$ 49,999$ & 19.2 & $28.1^{*}$ & $5.6^{*}$ & 20.2 & $2.0^{*}$ \\
\hline$\$ 50,000+$ & 5.8 & $12.7^{*}$ & $0.6^{*}$ & 6.9 & $0.4^{*}$ \\
\hline \multicolumn{6}{|c|}{$\begin{array}{l}\text { Annual hours expressed } \\
\text { as a percentage of } \\
\text { full-time, full-year } \\
\text { employment ( } 2080 \text { hours) }\end{array}$} \\
\hline $0 \%$ & 8.9 & $3.7^{*}$ & $29.2^{*}$ & 8.2 & $37.4^{*}$ \\
\hline $.01-24.99 \%$ & 3.1 & 1.4 & $8.2^{*}$ & 2.2 & 2.8 \\
\hline $25.00-49.99 \%$ & 4.1 & 2.1 & $6.6^{*}$ & 3.4 & $6.5^{*}$ \\
\hline $50.00-74.99 \%$ & 6.3 & 3.9 & 8.2 & 4.1 & $8.6^{*}$ \\
\hline $75.00-99.99 \%$ & 14.4 & $10.3^{*}$ & 14.0 & 35.8 & $15.4^{*}$ \\
\hline $100-109.99 \%$ & 38.8 & 43.2 & $26.9^{*}$ & 19.8 & 23.5 \\
\hline $110 \%+$ & 24.5 & $35.3^{*}$ & $7.0^{*}$ & 26.6 & $5.8^{*}$ \\
\hline \multicolumn{6}{|c|}{$\begin{array}{l}\text { Average hourly wage (those } \\
\text { with hours and earnings) }\end{array}$} \\
\hline$\$ 0.01-\$ 3.34$ & 5.5 & 3.3 & $12.9^{*}$ & 2.6 & $14.7^{*}$ \\
\hline \$3.35-\$3.99 & 2.5 & 1.7 & $6.2^{*}$ & 1.5 & $5.6^{*}$ \\
\hline$\$ 4.00-\$ 4.99$ & 7.4 & $3.2^{*}$ & 10.9 & 4.2 & $12.0^{*}$ \\
\hline$\$ 5.00-\$ 5.99$ & 10.1 & $4.4^{*}$ & 11.8 & 6.0 & $12.1^{*}$ \\
\hline$\$ 6.00-\$ 6.99$ & 5.7 & 4.6 & $11.1^{*}$ & 7.9 & 11.9 \\
\hline$\$ 7.00-\$ 7.99$ & 7.4 & 5.8 & 8.4 & 10.3 & 8.7 \\
\hline$\$ 8.00-\$ 9.99$ & 12.3 & 12.2 & 14.3 & 14.2 & 14.2 \\
\hline$\$ 10.00-\$ 14.99$ & 24.3 & 27.3 & $15.9^{*}$ & 29.2 & $14.7^{*}$ \\
\hline$\$ 15.00+$ & 24.9 & $37.5^{*}$ & $8.5^{*}$ & 24.1 & $6.1^{*}$ \\
\hline
\end{tabular}

Notes: SIPP data, reported for 1985, were inflated to 1989 using the Consumer Price Index. In the CPS and SIPP data, wages do not include anyone with self-employment or farm income. Sample sizes: 814 single fathers (676 for wages), 16,402 married fathers (14,112 for wages), and 4937 single mothers (3384 for wages) in the CPS; 385 fathers (345 for wages) and 2114 mothers (2074 for hours, 1052 for wages) in the SIPP. Widows and widowers were not included in either data source.

*The difference between the percentage of single mothers and single fathers (or married fathers and single fathers, or custodial mothers and custodial fathers) is significantly different from zero at the .05 level. 
TABLE 5

Welfare Recipiency of Mothers and Fathers: 1989 CPS and 1985 SIPP

\begin{tabular}{|c|c|c|c|c|}
\hline & \multicolumn{2}{|c|}{1989 CPS } & \multicolumn{2}{|c|}{1985 SIPP } \\
\hline & Single Fathers & Single Mothers & Custodial Fathers & - Custodial Mothers \\
\hline AFDC recipient & $6.0 \%$ & $30.2 \% *$ & $2.0 \%$ & $27.5 \% *$ \\
\hline Food Stamps recipient & 12.6 & $35.3^{*}$ & 6.1 & $35.6^{*}$ \\
\hline $\begin{array}{l}\text { Public housing } \\
\text { recipient }\end{array}$ & 3.7 & $17.2^{*}$ & 1.0 & $14.2^{*}$ \\
\hline $\begin{array}{l}\text { With children under } \\
15 \text { who receive } \\
\text { either Medicaid or } \\
\text { Medicare }\end{array}$ & 17.5 & $36.8 *$ & NA & NA \\
\hline $\begin{array}{l}\text { Recipient of any of } \\
\text { the above }\end{array}$ & 20.8 & $46.2^{*}$ & 7.2 & $43.6^{*}$ \\
\hline
\end{tabular}

Note: Sample sizes: 814 single fathers and 4937 single mothers in the CPS; 385 fathers and 2114 mothers in the SIPP. Widows and widowers were not included in either data source.

"For SIPP respondents, "any of the above" includes AFDC, Food Stamps, public housing, general assistance, and "other welfare." For CPS respondents, "any of the above" includes AFDC, Food Stamps, Medicaid, Medicare, and public housing.

*The difference between the percentage of single mothers and single fathers (or custodial mothers and custodial fathers) is significantly different from zero at the .05 level. 


\section{Child Support Information}

Table 6 shows information on the dollar amounts of child support due and received by custodial fathers and custodial mothers who are owed support. Because information on amounts due to custodial fathers are-not available in the national samples, we focus on results from Wisconsin. The first two columns show that custodial fathers are much less likely to have a child support award, with only 30 percent of the fathers who get custody through the court in Wisconsin obtaining a support award, compared to over 80 percent of custodial mothers. The awards are also smaller, a figure consistent with the lower earnings of noncustodial mothers and consistent with fathers having custody of fewer children. Among parents who are due child support, fathers are less likely to receive a payment, with 49 percent of fathers and 27 percent of mothers receiving nothing. However, of the fathers who received something $(n=59)$, half received the full amount due or more, a figure very similar to that for mothers.

The last two columns of Table 6 show custodial mothers from national data sources for comparison purposes. (However, the samples are different in that the Wisconsin data only include recent divorces and paternities, and only include women who have been to court.) Because the Wisconsin sample is drawn from court records, the higher percentage of mothers with awards in Wisconsin compared to the national sample is expected. Compliance figures, however, show a lower percentage of women receiving full payments in Wisconsin, perhaps because awards in Wisconsin are higher than in the nation as a whole.

Table 7 shows the dollar amount of child support received for the full sample. Whereas the last table looked at amounts received from a compliance perspective (compared to amounts due), this table looks at amounts received from the perspective of the amount of income provided by the noncustodial parent to help care for his or her children. The sample in this table is larger to capture 
TABLE 6

Percentage of Custodial Parents with Child Support Awards, Certain Award Amounts, and Who Have Received Payments: 1987 WCRD, 1985 SIPP, and 1987 CPS-CSS

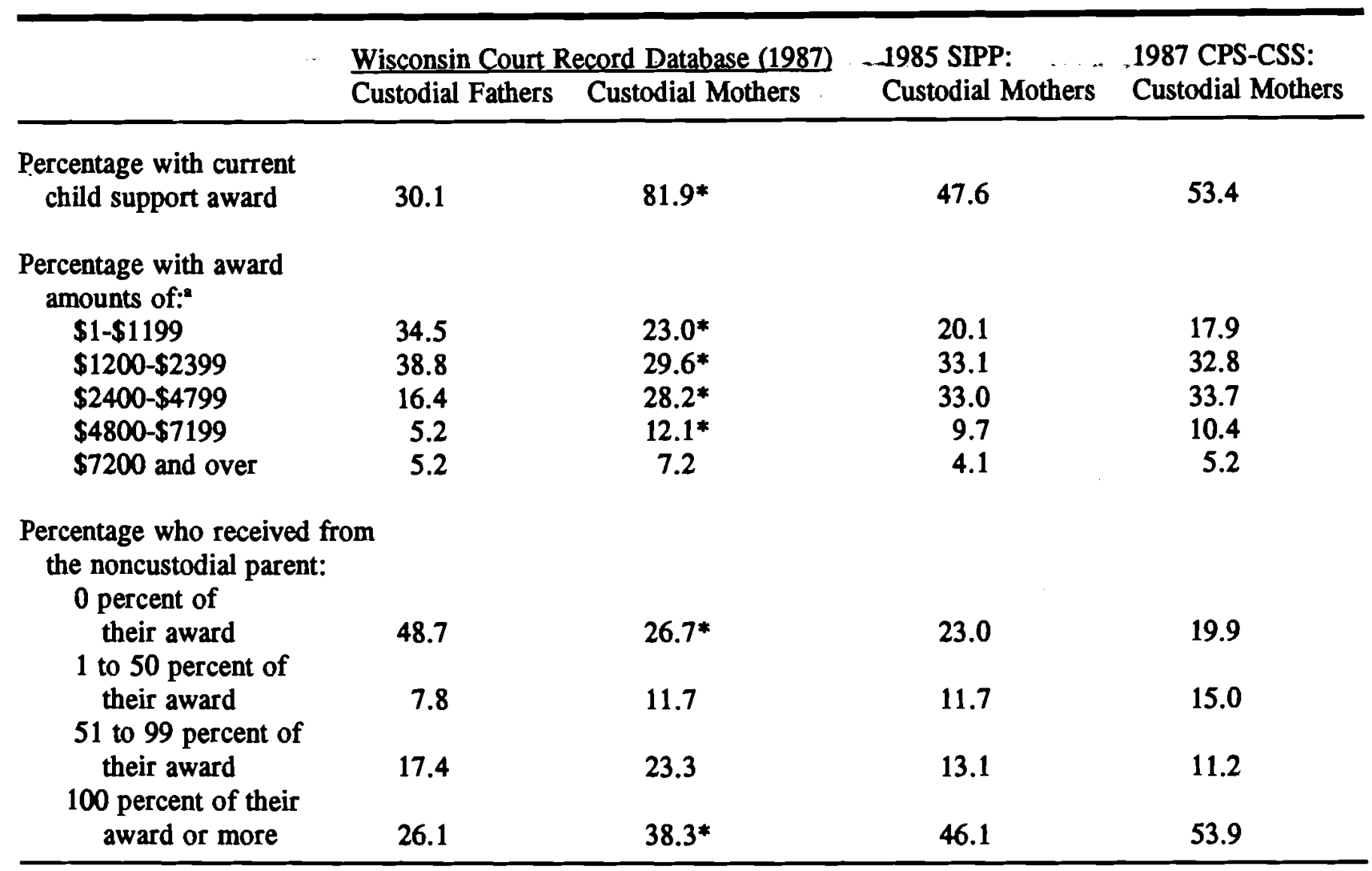

Notes: SIPP dollar amounts were reported for 1985. Nominal 1985 dollars were inflated to 1987 using the Consumer Price Index. 1987 WCRD includes July-December 1987 (times two for the annual amount due). Sample sizes: For the percentage with awards: 392 custodial fathers and 4680 custodial mothers in the WCRD; 2114 custodial mothers in the SIPP; 4279 custodial mothers in the CPS-CSS. For those with awards: 116 custodial fathers and 3808 custodial mothers in the WCRD; 1029 custodial mothers in the SIPP; 2215 custodial mothers in the CPS-CSS. Widows and widowers were not included in the SIPP.

"Conditional on having an award.

*The difference between the percentage of custodial mothers and custodial fathers is significantly different from zero at the .05 level. No comparisons were made between data sets. 
TABLE 7

Percentage of Custodial Parents Receiving Certain Amounts of Child Support Annually, Regardless of Award Status: 1987 WCRD and 1985 SIPP

Wisconsin Court Record Data Base (1987)

\begin{tabular}{|c|c|c|c|c|}
\hline \multicolumn{3}{|r|}{ Div Dara Dase (1701 } & \multirow{2}{*}{\multicolumn{2}{|c|}{ Custodial Fathers Custodial Mothers }} \\
\hline & Custodial Fathers & Custodial Mothers & & \\
\hline \multicolumn{5}{|c|}{$\begin{array}{l}\text { Percentage who received from the } \\
\text { noncustodial parent annual child } \\
\text { support amounts of: }\end{array}$} \\
\hline$\$ 0$ & 80.6 & $37.5^{*}$ & 96.0 & $63.3^{*}$ \\
\hline$\$ 1-\$ 1199$ & 8.6 & $17.6^{*}$ & 2.1 & $10.5^{*}$ \\
\hline$\$ 1200-\$ 2399$ & 6.5 & $14.7^{*}$ & 0.4 & $10.5^{*}$ \\
\hline$\$ 2400-\$ 4799$ & 3.0 & $17.7^{*}$ & 1.5 & $11.0^{*}$ \\
\hline$\$ 4800-\$ 7199$ & 1.0 & $7.8^{*}$ & 0.0 & $3.0^{*}$ \\
\hline$\$ 7200$ and over & 0.3 & $4.6^{*}$ & 0.0 & $1.7^{*}$ \\
\hline
\end{tabular}
1985 SIPP

Notes: Both samples contain all custodial fathers and mothers, even those with no child support awards. SIPP dollar amounts were reported for 1985. Nominal 1985 dollars were inflated to 1987 using the Consumer Price Index. 1987 WCRD includes July-December 1987 (times two for the annual amount received). Sample sizes: 397 custodial fathers and 4832 custodial mothers in the WCRD; 385 custodial fathers and 2114 custodial mothers in the SIPP. Widows and widowers were not included in the SIPP. Fathers and mothers with private pay agreements were deleted from the WCRD.

*The difference between the percentage of custodial mothers and custodial fathers is significantly different from zero at the .05 level. No comparisons were made between data sets. 
the possibility that some noncustodial parents provide support for their children even though they are not required to do so by the court.

In Wisconsin, fewer than 20 percent of the mothers paid child support, compared to more than 60 percent of the fathers, and the amounts paid by mothers were substantially lower. These amounts paid by mothers in Wisconsin, however, are much higher than the amounts paid by mothers in the national sample, in which less than 5 percent of noncustodial mothers are paying child support.

In summary, very few custodial fathers receive child support. The Wisconsin data suggest, however, that this is primarily because of a lack of awards, as about 70 percent of these fathers do not have awards. Even when there is an award, about half of noncustodial mothers pay nothing, although about one-fourth pay the full amount due.

\section{POLICY IMPLICATIONS}

Public policies related to child support are frequently founded around two assumptions: the mother always receives custody of the children, and the noncustodial parent always has the higher of the two incomes. While these assumptions still hold true for most child support cases, in a growing number of cases they are no longer valid. In light of the evidence presented here, we believe child support policies should be reexamined to ensure equity when the custodial parent is the father or when the custodial parent has a higher income than the noncustodial parent. Rather than present specific policy recommendations, we instead list specific areas of policy that might need further scrutiny.

For example, consider the state policies that set child support award amounts (federal policy is to allow each state to develop its own guideline formula). Some have argued that the guiding principle in setting awards should be to keep the noncustodial parent providing approximately the same percentage of income that he or she would have spent on the child(ren) if living with them. 
This sharing-income principle can be contrasted with a cost principle that would base child support awards on some measure of a child's basic needs. Note immediately that the two principles have very different implications when the noncustodial parent's income is lower than the custodial parent's: the cost view could very well lead to an award of zero if the custodial parent's income were deemed high enough to cover basic needs, while the sharing-income view would lead to a positive award regardless of how small the income of the noncustodial parent is because he or she would presumably have spent part of it on the child had he or she been living with that child.

Almost all of the guideline formulae in use are based on the income-sharing philosophy and consider parental income and the number of children involved. Evidence indicates, however, that the principle being applied may vary with the gender of the noncustodial parent when the noncustodial parent has little or no income. Specifically, regardless of how little a noncustodial father earns, he may be expected to provide some minimal amount for the support of his children. Often the same is not required of low-income noncustodial mothers. Christensen et al. (1990) argue that this preferential treatment of mothers is justified by the inequitable treatment women receive throughout society. We recommend that regardless of whether or not support is awarded when the noncustodial parent has little or no income, the underlying policy behind the determination of the award amount be consistent across genders.

A second area of policy that may be affected by these data is that of paternity establishment. Until fairly recently paternity establishment actions have only occurred as judicial processes; several states now have expedited nonjudicial paternity establishment processes, and many states allow for voluntary acknowledgment of paternity. These data show that an increasing number of children are living with their unmarried fathers. This trend should reinforce the arguments of those who want policies that enable paternity to be established in a simple and straightforward manner. 
Currently, the United States does not have a federal child custody policy (physical or legal), and we are not advocating that one is needed. Most believe that the courts have been predisposed to give custody to the mother. However, the results presented here indicate that a shift may have occurred in that the mother no longer is automatically awarded sole physical and legal custody. While some may applaud this change for philosophical reasons and others may denounce it, further research on the effects of different custody arrangements on the well-being of children is needed, particularly research that examines the effects of a variety of custody arrangements on children's development, following Zill (1988) and others.

In summary, we believe many child support policies were established under the assumption that women would have sole physical custody of their children. We believe policies must be reexamined to ensure that they are appropriate for all the diverse custody arrangements that are appearing today. 
References

Amato, P. R. (1987). "Family Processes in One-Parent, Stepparent, and Intact Families: The Child's Point of View." Journal of Marriage and the Family 49: 327-337.

Bartz, K. W. \& Witcher, W. C. (1978). "When Fathers Get Custody." Children Today 7(5): 2-6.

Chang, P. \& Deinard, A. S. (1982). "Single-Father Caretakers: Demographic Characteristics and Adjustment Processes." American Journal of Orthopsychiatry 52: 236-243.

Christensen, D. H., Dahl, C. M., \& and Rettig, K. D. (1990). "Noncustodial Mothers and Child Support: Examining the Larger Context." Family Relations 39: 388-394.

Demo, D. H. \& Acock, A. C. (1988). "The Impact of Divorce on Children." Journal of Marriage and the Family 50: 619-648.

Ellwood, D.T. (1988). Poor Support: Poverty in the American Family. New York: Basic Books.

Furstenberg, F. F. Jr., Nord, C. W., Peterson, J. L., \& Zill, N. (1983). "The Life Course of Children of Divorce: Marital Disruption and Parental Contact." American Sociological Review 48: 656-668.

Garfinkel, I., Corbett, T. J., MacDonald, M., McLanahan, S., Robins, P. K., Schaeffer, N. C., \& Seltzer, J. A. (1988). "Evaluation Design for the Wisconsin Child Support Assurance Demonstration." Report produced under contract with the Wisconsin Department of Health and Social Services. Madison, Wis.: University of Wisconsin-Madison, Institute for Research on Poverty.

Garfinkel, I. \& McLanahan, S. S. (1986). Single Mothers and Their Children: A New American Dilemma. Washington, D.C.: The Urban Institute Press.

Gasser, R. D. \& Taylor, C. M. (1976). "Role Adjustments of Single Fathers with Dependent Children." Family Coordinator 25: 397-401. 
Gersick, K. E. (1979). "Fathers by Choice: Divorced Men Who Receive Custody of Their Children." In G. Levinger and O. Noles (eds.), Separation and Divorce. New York: Basic Books.

Glenn, N. D. \& Kramer, K. B. (1987). "The Marriages and Divorces of the Children of Divorce." Journal of Marriage and the Family 49: 811-825.

Greif, G. L. (1985). "Single Fathers Rearing Children." Journal of Marriage and the Family 47: 185-191. (1987). " A Longitudinal Examination of Single Custodial Fathers: Implications for Treatment." The American Journal of Family Therapy 15: 253-260. (1990). The Daddy Track and the Single Father. Lexington, Mass.: Lexington Books.

Hanson, S. M. H. (1988). "Divorced Fathers with Custody." In P. Bronstein \& C. P. Cowan (eds.), Fatherhood Today: Men's Changing Role in the Family. New York: John Wiley and Sons.

Hofferth, S. L. (1985). "Updating Children's Life Course." Journal of Marriage and the Family 47: $93-115$.

Lewis, K. (1978). "Single-Father Families: Who They Are and How They Fare." Child Welfare 57: 643-651.

McLanahan, S. \& Booth, K. (1989). "Mother-Only Families: Problems, Prospects, and Politics." Journal of Marriage and the Family 51: 557-580.

Mendes, H. A. (1976). "Single Fatherhood." Social Work 21: 308-312.

Orthner, D., Brown, T., \& Ferguson, D. (1976). "Single Parent Fatherhood: An Emerging Family Life Style." Family Coordinator 25: 429-437.

Pearson, J., Munson, P., \& Thoennes, N. (1982). "Legal Change and Child Custody Awards." Journal of Family Issues 3: 5-24. 
Pearson, J., \& Thoennes, N. (1985). "Child Custody, Child Support Arrangements, and Child Support Payment Patterns." Juvenile \& Family Court Journal 36: 49-56.

Price-Bonham, S. (1976). "Bibliography of Literature Related to Roles of Fathers." The Family Coordinator 25: 489-512.

Risman, B. J. (1986). "Can Men 'Mother'? Life as a Single Father." Family Relations 35: 95-102. (1987). " Intimate Relationships from a Microstructural Perspective: Men Who Mother." Gender and Society 1: 6-32.

Risman, B. J. with Park, K. (1988). "Just the Two of Us: Parent-Child Relationships in SingleParent Homes." Journal of Marriage and the Family 50: 1049-1062.

Rosenthal, K. M. \& Heshet, H. F. (1981). Fathers without Partners: A Study of Fathers and the Family after Marital Separation. Totowa, N.J.: Rowman and Littlefield.

Ross, H. \& Sawhill, I. (1975). Time of Transition: The Growth of Families Headed by Women. Washington, D.C.: The Urban Institute Press.

Santrock, J. W. \& Warshak, R. A. (1979). "Father Custody and Social Development in Boys and Girls." Journal of Social Issues 35(4): 112-125.

Seltzer, J. A. (1990). "Legal and Physical Custody Arrangements in Recent Divorces." Social Science Ouarterly 71: 250-266.

Spanier, G. B. (1983). "Married and Unmarried Cohabitation in the United States: 1980." Journal of Marriage and the Family 45: 277-288.

Stack, C. B. (1976). "Who Owns the Child? Divorce and Child Custody Decisions in Middle-Class Families." Social Problems 23: 505-515.

Zill, N. (1988). "Behavior, Achievement, and Health Problems among Children in Stepfamilies: Findings from a National Survey of Child Health." In E. M. Hetherington \& J. D. Arasteh 
(eds.), Impact of Divorce Single Parenting and Stepparenting on Children. Hillsdale, N.J.: Lawrence Erlbaum Associates. 